\title{
Fusion of permanent maxillary right central incisor and mesiodens in an 8-year-old child
}

\author{
Rehan Khan, ${ }^{1}$ Pratik B Kariya, ${ }^{2}$ Rachappa Mallikarjuna, ${ }^{2}$ Atul N Singh ${ }^{3}$
}

${ }^{1}$ Department of Pedodontics and Preventive Dentistry, Saraswati Dhanwantari Dental College \& Hospital, Parbhani, Maharashtra, India

${ }^{2}$ Department of Pedodontics and Preventive Dentistry, KM Shah Dental College and Hospital, Sumandeep Vidyapeeth, Vadodara, Gujarat, India

${ }^{3}$ Department of Pedodontics and Preventive Dentistry, BBDCODS, Lucknow, Uttar Pradesh, India

Correspondence to Dr Rachappa Mallikarjuna, mmrachappa@gmail.com

Accepted 20 December 2014

\section{DESCRIPTION}

Fusion of the teeth is a developmental anomaly that may occur due to joining of the two separated tooth germs. It may be complete or incomplete based on which stage of development the fusion occurred. Physical forces or pressure may cause fusion. It can be seen between the two primary teeth or permanent teeth or between normal and supernumerary teeth, commonly mesiodens. ${ }^{1}$

In this case, an 8-year-old boy presented with a 'large tooth' in the upper front region of his jaw. Traumatic or familial history did not reveal anything. On complete intraoral examination, it was found that the permanent maxillary right central incisor was larger mesiodistally than the left one, which can signify the possibility of fusion between central incisor and mesiodens (figure 1). The boy also had proximal caries with $53,63,74,75$ and 84 , and deep

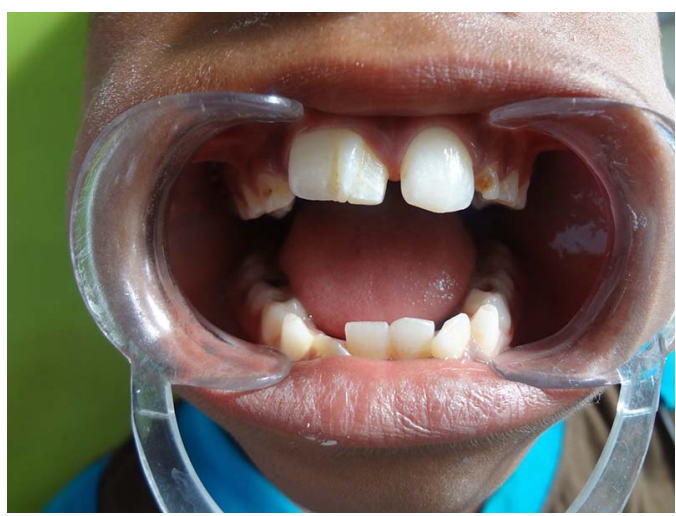

Figure 1 Intra oral photograph showing fusion of the permanent maxillary central incisor and mesiodens. occlusal caries with 85 . Thus, instead of intraoral periapical radiographs, an orthopantomogram was advised to check the extent of caries in all four quadrants as well as to evaluate the root status of the fused teeth. The extraoral radiograph revealed that the fused teeth had an underdeveloped single large root with a single large root canal (figure 2).

It is often difficult or impossible to differentiate between fusion and gemination clinically or radiographically when normal and supernumerary teeth are involved. ${ }^{2}$ The treatment for such a condition is multidisciplinary, involving endodontics, periodontics and orthodontics to achieve good results. ${ }^{3}$

\section{Learning points}

- An orthopantomogram or intraoral periapical radiograph is often required to evaluate the root status of fused teeth.

- Differential diagnosis of fusion and gemination is difficult when normal and supernumerary teeth are involved.

- A multidisciplinary approach is required to treat such a condition.

Twitter Follow Rachappa Mallikarjuna at @rachappa Competing interests None.

Patient consent Obtained.

Provenance and peer review Not commissioned; externally pee reviewed.
To cite: Khan $R$, Kariya $P B$, Mallikarjuna R, et al. BMJ Case Rep Published online: [please include Day Month Year] doi:10.1136/bcr-2014208541

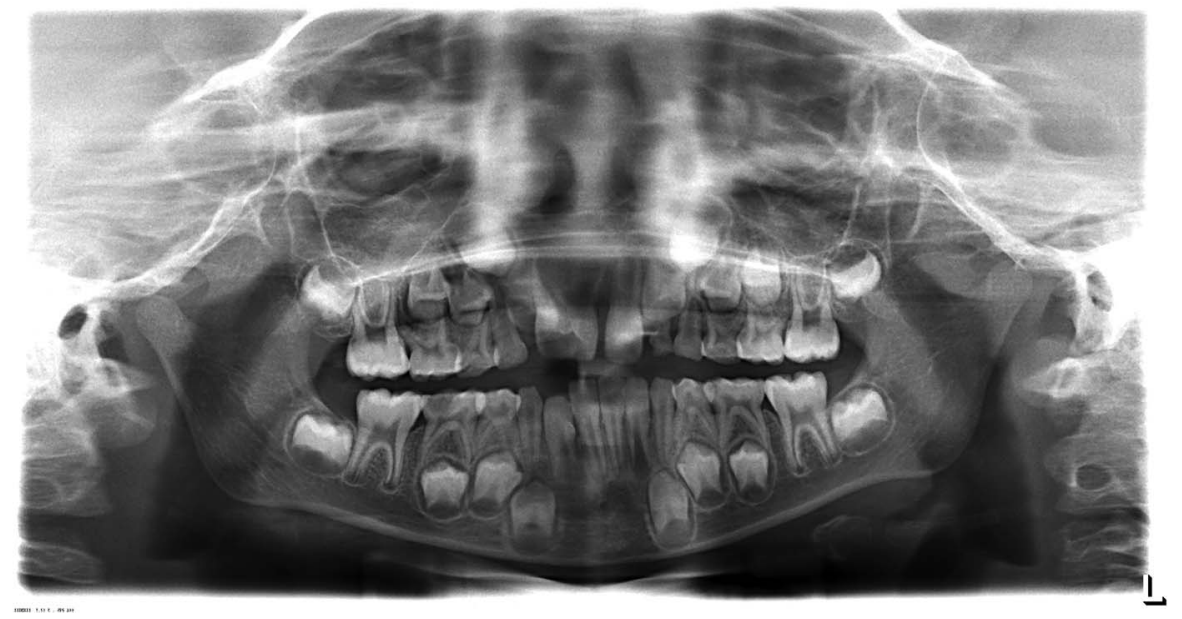

Figure 2 Orthopantomogram of an 8-year-old child showing single large root and root canal of fused teeth in maxillary arch. 


\section{REFERENCES}

1 Shafer WG, Hine MK, Levy BM. A textbook of oral pathology. 7th edn. Philadelphia: W B Saunders, 2012:41.
2 Evcil MS, Ozcan E, Koseoglu M, et al. Endodontic treatment of maxillary central incisor with anomalous root formation—a case report. Ataturk Univ Diş Hek Fak Derg 2009;19:203-6.

3 Good DL, Berson RB. A supernumerary tooth fused to a maxillary permanent central incisor. Pediatr Dent 1980;2:294-6.

Copyright 2015 BMJ Publishing Group. All rights reserved. For permission to reuse any of this content visit

http://group.bmj.com/group/rights-licensing/permissions.

BMJ Case Report Fellows may re-use this article for personal use and teaching without any further permission.

Become a Fellow of BMJ Case Reports today and you can:

- Submit as many cases as you like

- Enjoy fast sympathetic peer review and rapid publication of accepted articles

- Access all the published articles

- Re-use any of the published material for personal use and teaching without further permission

For information on Institutional Fellowships contact consortiasales@bmjgroup.com

Visit casereports.bmj.com for more articles like this and to become a Fellow 